\title{
DOSTALÍK, P. Nakládání s cizí věcí v soukromém právu.
}

Praha: Leges, 2019, 151 s.

Recenzovaná monografie P. Dostalíka je věnována jedné z mimořádně zajímavých otázek, nebo spíše komplexu problémů, soukromého práva, samozřejmě nejen v kontextu práva římského. Pod souhrnným označením „nakládání s cizí věcí“ přitom musíme rozumět různé př́pady, kdy osoba odlišná od vlastníka věci má, nebo spíše v důsledku vzniku konkrétní situace, jí vzniká, nebo snad můžeme dokonce říci, že je jí právním řádem uděleno, určité oprávnění chovat se $\mathrm{k}$ cizí věci způsobem, který by za normálních okolností měl za následek vznik deliktní odpovědnosti. Celá problematika není přitom zkoumána z pohledu ř́mského práva, ale právní romanistiky. Kromě ř́mského práva totiž autor na dané otázky nahlíží také z úhlu práva pandektního. Vedle toho P. Dostalík zkoumá také úpravu obsaženou v rakouském právu, přičemž se nejedná pouze o ABGB, ale také o Codex Theresianus. Samozřejmě se rovněž zabývá vývojem československého práva, počínaje vládním návrhem z roku 1937, přes občanské zákoníky z let 1950 i 1964, a výklady zakončuje současnou právní úpravou.

Kniha se člení na šest kapitol, přičemž prvních pět je zaměřeno na jednotlivé právní instituty vážící se ke zkoumané problematice. Nejprve je analýze podroben př́rístek (accessio), a to ve všech jeho podobách, tedy v různých kombinacích trvalého spojení movitých a nemovitých věcí.

Následující dvě kapitoly jsou věnovány případům, které mají společného jmenovatele. Jedná se o alluvio a avulsio, tedy naplaveninu a odtržení, přičemž druhý uvedený př́pad autor překládá jako „strž“. V další kapitole se autor zaměřil na př́ípad označovaný jako zpracování (specificatio).

Versio in rem je název další kapitoly obsahující výklady o jedné z praetorských žalob sloužících k odškodnění osoby, která vstoupila do právního vztahu s otrokem nebo synem podřízeným otcovské moci s tím, že ti nebyli $\mathrm{k}$ takovémuto jednání zmocněni. Také $\mathrm{v}$ tomto případě dochází často $\mathrm{k}$ nakládání $\mathrm{s}$ cizí věcí ( $\mathrm{v}$ tomto konkrétním př́ípadě věřitele). Předposlední kapitola je zasvěcena známému institutu lex Rhodia de iactu. Také v př́padech ošetřených tzv. Rhodským zákonem dochází k nakládání s cizí věcí (věcmi vlastníků, jejichž zboží je $\mathrm{v}$ případě nouze vyhozeno) a stejně tak i k obohacení vlastníků zachráněného zboží. Závěrečná kapitola nazvaná „Nakládání s cizí věcí v krajní nouzi“ je pak věnována právě tomuto aspektu zkoumané problematiky, přičemž se autor zaměřil nejen na vývoj pojetí tohoto institutu vycházejícího nepochybně z „Rhodského zákona“, ale také na institut tzv. společné nouze. 
Bylo by samozřejmě možné namítat, že se autor ve zkoumaných souvislostech detailně nevěnoval veškeré předchozí právní úpravě platné na našem území, jako je například Koldínův zákoník, nebo dalším kodifikacím soukromého práva (např. Code civil, Codice civile italiano atp.), př́ipadně že měl záběr své monografie rozššřit také na jiné instituty. Nicméně je na tomto místě třeba konstatovat známou pravdu, že výběr tématu, stejně jako jeho konkrétní zaměření, je vždy navýsost autorskou licencí.

Potěšitelné na této knize je mimo jiné i to, že P. Dostalík potvrzuje, že je právním romanistou, a proto také v seznamu použité literatury nepřevažují anglicky píšící autoři, ani se citovaná literatura neomezuje pouze na dva jazyky, což je v poslední době bohužel u odborné (vědomě není použito slovo vědecké, protože se o takovou nejedná) literatury stále více a více opakujícím se jevem (nutno podotknout, že nikoli v romanistické literature).

Knihu standardně doprovází seznam použité literatury, stejně jako seznam použitých zkratek a u romanistických prací obvyklý rejstřík použitých pramenů. Za zmínku jistě stojí, že autor nepracoval pouze s těmi prameny, se kterými se běžně u takových prací setkáváme, jako jsou Digesta, Gaiova „učebnice“, justiniánské Instituce, nebo Codex, ale využil také prameny méně obvyklé, a zároveň je třeba říci, že rovněž obtížně interpretovatelné, jakým je Cuiacius.

Závěrem je také třeba připomenout, že Dostalíkova kniha navazuje na jeho předchozí práce, jako je „Condictiones: ke kořenům bezdůvodného obohacení““ (Praha, 2018) nebo spoluautorství na monografii „Geneze kodifikací mezinárodního práva soukromého: soukromoprávní úpravy mezinárodních poměrů“ (Praha, 2019).

Společným jmenovatelem celé studie je to, že se jedná o případy obohacení sine condictio, tedy takové, které nebylo možné žalovat pomocí kondikce z bezdůvodného obohacení. Právě proto, že žádná z běžných kondikcí použitelná nebyla, nicméně u jedné ze stran vztahu došlo k navýšení stavu jejího majetku (pod klasické obohacení, tak jak je běžně chápáno, tedy tyto př́pady subsumovat nelze), byly v klasickém právu používány, jak správně autor konstatuje, jiné nástroje, jako je actio ad exhibendum, reivindicatio utilis, actio de in rem verso, prrípadně exceptio doli.

Jedná se o cenný příspěvek napomáhající pochopení vývoje institutu obohacení v historickém právním evropském kontextu. Podnětnější je tato kniha o to více, že autor použil komparativní metodu.

Michal Skřejpek

doi: 10.14712/2464689X.2021.37 